\title{
Evaluation on the Effectiveness of Using 3D Rat Model for Teaching Blood Withdrawal Technique among Undergraduate Students
}

\author{
Santhra Segaran Balan ${ }^{1,2}$, Sitell Maya ${ }^{2}$, Azrina Zainal Abidin ${ }^{1,2}$, Muhammad Fuad $^{3}$, Fezah Othman $^{4}$, \\ Hasnah Bahari,"* \\ ${ }^{1}$ Department of Human Anatomy, Faculty of Medicine and Health Sciences, Universiti Putra Malaysia, Malaysia \\ ${ }^{2}$ Faculty of Health and Life Sciences, Management and Science University, Malaysia \\ ${ }^{3}$ Department of Biological and Agricultural Engineering, Faculty of Engineering, Universiti Putra Malaysia, Malaysia \\ ${ }^{4}$ Department of Biomedical Sciences, Faculty of Medicine and Health Sciences, Universiti Putra Malaysia, Malaysia
}

Received August 3, 2020; Revised September 30, 2020; Accepted October 19, 2020

\section{Cite This Paper in the following Citation Styles}

(a): [1] Santhra Segaran Balan, Sitell Maya, Azrina Zainal Abidin, Muhammad Fuad, Fezah Othman, Hasnah Bahari, "Evaluation on the Effectiveness of Using 3D Rat Model for Teaching Blood Withdrawal Technique among Undergraduate Students," Universal Journal of Educational Research, Vol. 9, No. 1, pp. 10 - 16, 2021. DOI: 10.13189/ujer.2021.090102.

(b): Santhra Segaran Balan, Sitell Maya, Azrina Zainal Abidin, Muhammad Fuad, Fezah Othman, Hasnah Bahari (2021). Evaluation on the Effectiveness of Using 3D Rat Model for Teaching Blood Withdrawal Technique among Undergraduate Students. Universal Journal of Educational Research, 9(1), 10 - 16. DOI: 10.13189/ujer.2021.090102.

Copyright $\bigcirc 2021$ by authors, all rights reserved. Authors agree that this article remains permanently open access under the terms of the Creative Commons Attribution License 4.0 International License

\begin{abstract}
Usage of 3D model in medical education is very important in this era as part of $21^{\text {st }}$ century teaching method. Application of 3D printing model in medical education helps to improve student spatial visualization skill and also will increase their interest in difficult topic or subject specifically in the science-based issue. This study aims to evaluate the effectiveness of using a 3D rat model for teaching blood withdrawal techniques among undergraduate students. Workshop of usage of 3D model rat was conducted among all students. Students were exposure to classical teaching method of blood withdrawal and follow by workshop using 3D rat model. A set of questionnaire was given to students before and after usage of 3D- printed rat model. Data collected used a questionnaire consisting of socio-demographic, pre and post- test question and assessment towards 3D models. A total of 117 participants were tested. 3D-printed rat model was used as part of the paired sample t-test. The result supported the hypothesis that the 3D-printed rat model in teaching blood withdrawal techniques is more effective compared to the using classical teaching method in the classroom $(p<0.05)$. Study also showed that students satisfy with usage of 3D model for teaching blood
\end{abstract}

withdrawal techniques. This study further demonstrated the 3D print rat model is beneficial for interactive education and enriching student learning capacity.

Keywords Three-dimensional (3D), Anatomy, Blood Withdrawal, Rat

\section{Introduction}

Over the past two decades, educational innovations have grown dramatically, leading to massive improvements in current technologies and the development of new methods [1]. Changes or innovation in education is a frequently referenced 21st-century sub-expertise, yet it's characterized in multiple ways. Various associations have created structures that endeavor to distinguish the individual aptitudes and sets of abilities undergraduate students need to succeed and to assist instructors with coordinating 21st-century skills into existing training programs [2]. Scientists and technologists are continually creating various applications and tools for students' use, such as 
digital courseware, augmented reality and some of the virtual reality present in the markets. The goal of using the innovation is not to replace traditional methods of teaching and learning, but also to include an alternative helped learning resource for certain areas that require further focus [7].

Modelling-based Instruction (MBI) is mainly focused on students-centered of science which requires the learner to create their own understanding and external representation of science concept and also to gain the understanding of science concept and solve the problem. MBI also refer as learner ability to communicate the details of science concept. The main goal of this MBI model is basically to create students centered learning and help to understand the deeper of science concept. Apart from that, this is also able to solve the issue independently [3]. This model encourages students to use, develop, share and test models to reflect and explain scientific processes and phenomena. Several empirical studies have confirmed the efficacy of MBI, with research findings indicating that it enhances students understanding of scientific material. Advancing technologies like three-dimensional (3D) printing and programming offer application to science education as a promising technology [1]. To be successful in the $21 \mathrm{st}$ century's new digital and globalized environment, individuals must have and use a wide range of learning and innovation skills related to information, media and technology [3].

Three-dimensional (3D) printing medical applications are rapidly expanding and are intended to change health care radically. Medical applications for 3D printing, whether real or potential, can be categorized into a few broad areas, including tissue and organ manufacturing, custom prosthetics, implants and anatomical models, and pharmaceutical research on drug dosage forms [4]. Visualization tools at the undergraduate level are among the most relevant techniques for learning. Due to the essential role of perceiving, interpreting and manipulating 3D spatial relationships for learning and problem-solving in many sciences, educational researchers have made considerable efforts to develop and incorporate visualization resources for science students [5]. The rapid development of $3 \mathrm{D}$ printing has created a new learning and teaching tool for medical education [6]. Furthermore, 3D printing technology is growing very fast and cost-effective for people to use. The accessibility of usage and downloadable software for 3D from online repositories is currently more accessible. The ability to develop products cheaply is another distinct advantage provided by 3D-printing. For massive-scale production, traditional manufacturing methods remain less costly; nevertheless, the cost of 3D printing is increasingly competitive for small production runs, mainly due to increasing requirements and lower costs [4].

$3 \mathrm{D}$ printing techniques may offer a novel and adequate substitute by reproducing accurate complex anatomical organs such as heart, muscle, etc. Besides, the ability of 3D printing to print many copies of any anatomical subject in different sizes gives a significant advantage in training facilities [8]. The ability to imagine and manipulate 3D structures mentally and accurately recognize them and associated structures is an essential skill for medical students when the anatomy is viewed at different levels and positions. Research in this area would not only analyze student's visual-spatial skills while learning, but it will also evaluate the development of technology to strengthen students learning capabilities and advance professional training [9].

Every year, 3D-printing provides more healthcare technologies to enrich and ultimately save lives in ways that have never been considered before. 3D printing is widely used in a broad range of healthcare settings [10]. Including medicine, $3 \mathrm{D}$ printing has become a valuable and possibly revolutionary method. Applications printer capacity, resolution, and available material have all increased. Researchers strive to use 3D-printing technology to develop current medical techniques and invent new ones. Creating medical advances with 3D printing are essential and exciting [4].

The number of laboratory animals used for scientific and other purposes has been steadily rising during recent years. The growing use of transgenic animals is a major contributory factor to current trend [25]. Millions of laboratory animals are used throughout the world every year. For a long time, the suffering, discomfort and death suffered by the animals during scientific experiments was a controversy topic. The logic is that animals have the right to against pain and suffer and therefore their use for research is immoral and must be limited. Several forms of actions and laws were passed to regulate illegal animal use and reduce animal suffering during experiments [20]. According to Taylor, et al (2008), consequently, until now the estimation of the worldwide annual laboratory animal use statistics has been wide ranging and inaccurate. They include estimation of 100-200 million in 1970, 60-85 million in 1993, and 50-100 million in 2005. The over production of animal is ethically undesirable, wasteful and costly. So, the main purpose of this research is to introduce the 3D model of rats for teaching the blood withdrawal technique by reducing the usage of real rats for teaching and learning purposed.

\section{Materials and Methods}

\subsection{Study Design}

Ethical approval was obtained from the Human Ethical Committee at Management and Science University (MSU) (MSU-RMC-02/FR01/06/L1/004). A consent form 
together with a questionnaire was provided to all participants. Five 3D printed rats' models were created by using $3 \mathrm{D}$ printing and AutoCAD software. All the $3 \mathrm{D}$ rats were evaluated and validated by an expert with experience in animal handling and blood withdrawal technique. This questionnaire was adopted and modified from Alvarez, Parra, \& Tubio (2015). Workshop was conducted among all undergraduate students. A demonstration of the blood withdrawal method was performed for the participant and before they were exposed to the 3D model. Students were given time to be exposed to the model and then were asked to complete the post survey portion of the questionnaire

\subsection{Data Collection}

Final year undergraduate biomedical student of the Management and Science University was the participant in the study. A total of 117 students participated. A confidential questionnaire containing the study information and consent form were distributed to the participants. The information provides to the participants included the objective of the study and direction to complete the pre-survey portion of the questionnaire. The results were collected and kept private and confidential. For this survey, we only use number codes to link the participant to the questionnaire. Name, address or any identification number was not asked from participant to make sure confidential and privacy of participant.

\subsection{Statistical Analysis}

Statistical analysis was performed using IBM SPSS 25.0, and the results were expressed as mean \pm standard deviation. All data were analysed using a normality test. Socio-demographic factor were analysed by frequency test and for pre and post-questionnaires were analysed using a paired sample t-test. A probability of $\mathrm{p}<0.05$ was considered to be statistically significant. The primary aim of the paired sample t-test is to determine whether there is any significant difference or change in values for a particular numerical variable between two occasions for the same subjects.

\section{Results}

\subsection{Descriptive Statistics on Socio-demographic}

Table 1 presents the descriptive statistics for the participant in intervention workshop. A total of 117 students participants were in the workshop. Of this total number, $13.7 \%(\mathrm{n}=16)$ are males and $86.3 \%(\mathrm{n}=101)$ are female undergraduate students. The ethnicities of the participant are Malay (50.4\%), followed by Indian (32.5\%), Chinese $5 \%$ and others (12.0\%).

\subsection{Pre and Post Survey}

Table 2 shows a summary of the pre- and post-survey that have been answered by all participants. A total of 13 different questions have been asked as pre-and post-question. Understanding of site of blood withdrawal in rats showed a significant improvement $(\mathrm{p}<0.05)$ among the participant with mean different 1.00. It shows that the participant have a more and clear understanding of blood withdrawal techniques after exposure to the 3D rat model compared to before the exposure. Interestingly, results from this study also revealed that the participant were more confident in handling the $3 \mathrm{D}$ rat model $(\mathrm{p}<0.05)$ and have a better understanding $(\mathrm{p}<0.05)$ on the theories of blood withdrawal techniques compared before the exposure of 3D model of rats. As expected, results from this study also indicated that the students were more confident $(p<0.05)$ in performing the blood withdrawal technique using the $3 \mathrm{D}$ rat model as the element of stress and death as in real rats can avoid. The students also agreed that the usage of the 3D rat model as a teaching tool is more beneficial to them compared to the traditional/conventional method. Besides, the students also displayed good knowledge on animal handling ethics, specifically in blood withdrawal techniques. As for the question on the implementation of 3D rat model in class, student's good feedback $(\mathrm{p}<0.05)$ indicated that the application of 3D rat model benefitted the student's skills and assessment practices. They also agreed that the usage of this $3 \mathrm{D}$ rat model would improve their knowledge and understanding of the blood withdrawal techniques compared to the traditional method (Table 2).

\subsection{Feedback on 3D Rat Model Assessment}

Table 3 shows a summary of assessment of 3D rat model answer by all participants. The result describes the level of attraction of participants had towards the 3D printed rat model; especially how much confidence can they gain after exposure to the $3 \mathrm{D}$ printed rat model. $13.7 \%$ of participants have neutral thought on the model, followed by $50.4 \%$ of has agreed, and $35.9 \%$ of participant have strongly agreed. The participant also had agreed on the good appearance and excellent quality of the 3D printed rat model. Regarding the easiness and attractiveness of the 3D printed model, $12.8 \%$ of participants have chosen neutral, followed by $41.9 \%$ of have agreed and $45.3 \%$ have strongly agreed on the handling of the $3 \mathrm{D}$ printed rat model. It shows that participants are happy and attracted to the model. In term of the durability of the 3D rat model, $44.4 \%$ of participants strongly agreed, followed by $38.5 \%$ of the agreed and $16.2 \%$ of the are neutral, and only $0.9 \%$ disagreed. The majority of the participant, $44.4 \%$ are strongly agreed that the usage of $3 \mathrm{D}$ rat model is good and a quick method for teaching blood withdrawal technique followed by $48.7 \%$ also strongly agreed that the $3 \mathrm{D}$ model is very comfortable, easy and familiar for usage in the classroom (table 3 ). 
Table 1. Descriptive statistics on socio-demographic factor

\begin{tabular}{ccc}
\hline Socio- Demographic Factor & $\mathrm{n}=117$ & $\%$ \\
\hline Gender & 16 & 13.7 \\
Male & 101 & 86.3 \\
Female & & 50.4 \\
Ethnicity & 59 & 32.5 \\
Malay & 38 & 5.1 \\
Indian & 6 & 12.0 \\
Chinese & 14 & 97.4 \\
Others & 3 & 2.6 \\
\hline Marital status & 314 & 98.3 \\
Married & & 1.7 \\
\hline Nationality & 115 & \\
\hline
\end{tabular}

Table 2. Pre-and post-survey comparison for clear understanding of the site of blood withdrawal in rats. Data was expressed as mean $\pm \mathrm{SD}$ and were analyzed using the paired t-test.

\begin{tabular}{|c|c|c|c|c|}
\hline & Pre-test Mean \pm SD & $\begin{array}{c}\text { Post-test } \\
\text { Mean } \pm \text { SD }\end{array}$ & $\begin{array}{c}\text { Mean } \\
\text { difference. }\end{array}$ & $\begin{array}{l}\text { Sig. } \\
\text { p value }\end{array}$ \\
\hline $\begin{array}{l}\text { I had/have a clear understanding of side of } \\
\text { blood withdrawal in rats. }\end{array}$ & $3.07 \pm 1.03$ & $4.07 \pm 0.74$ & 1.00 & $\mathrm{p}<0.05$ \\
\hline $\begin{array}{l}\text { I was/can handle the rats with confident to } \\
\text { withdraw the blood. }\end{array}$ & $2.98 \pm 1.04$ & $4.07 \pm 0.75$ & 1.09 & $\mathrm{p}<0.05$ \\
\hline $\begin{array}{l}\text { I had/have a clear understanding of theories } \\
\text { of blood withdrawal. }\end{array}$ & $3.06 \pm 0.94$ & $4.21 \pm 0.62$ & 1.15 & $\mathrm{p}<0.05$ \\
\hline $\begin{array}{l}\text { I had/have confidence in my ability to } \\
\text { withdraw the blood without giving stress to } \\
\text { the rats. }\end{array}$ & $2.81 \pm 0.90$ & $3.99 \pm 0.80$ & 1.18 & $\mathrm{p}<0.05$ \\
\hline $\begin{array}{l}\text { I had/have confidence in my ability to } \\
\text { withdraw the blood without cause death to } \\
\text { rats }\end{array}$ & $2.81 \pm 0.93$ & $4.00 \pm 0.78$ & 1.19 & $\mathrm{p}<0.05$ \\
\hline $\begin{array}{l}\text { I had/have a clear understanding of the } \\
\text { ethic of animal handling, specifically in } \\
\text { blood withdrawal method. }\end{array}$ & $2.81 \pm 0.93$ & $4.00 \pm 0.78$ & 1.19 & $\mathrm{p}<0.05$ \\
\hline $\begin{array}{l}\text { I had/have a clear understanding of how to } \\
\text { use proper equipment for blood withdrawal } \\
\text { in rats (example: syringe and needle) }\end{array}$ & $3.24 \pm 0.98$ & $4.27 \pm 0.60$ & 1.03 & $\mathrm{p}<0.05$ \\
\hline $\begin{array}{c}\text { Do you believe 3D printing model suitable } \\
\text { for teaching blood withdrawal methods in } \\
\text { rats? }\end{array}$ & $3.82 \pm 0.99$ & $4.40 \pm 0.66$ & 0.58 & $\mathrm{p}<0.05$ \\
\hline $\begin{array}{l}\text { Do you believe 3D model Implementation } \\
\text { in teaching and assessment practices of } \\
\text { blood withdrawal will benefit students? }\end{array}$ & $3.82 \pm 0.99$ & $4.40 \pm 0.66$ & 0.58 & $\mathrm{p}<0.05$ \\
\hline $\begin{array}{l}\text { Do you believe 3D model Implementation } \\
\text { in teaching will change the way of } \\
\text { teaching, understanding the method? }\end{array}$ & $3.96 \pm 0.96$ & $4.49 \pm 0.64$ & 0.53 & $\mathrm{p}<0.05$ \\
\hline $\begin{array}{l}\text { I had/have a general understanding of the } \\
\text { blood withdrawal technique in rats. }\end{array}$ & $3.33 \pm 1.02$ & $4.20 \pm 0.60$ & 0.087 & $\mathrm{p}>0.05$ \\
\hline $\begin{array}{l}\text { I had/have high confidence in my ability to } \\
\text { withdraw the blood from rats. }\end{array}$ & $2.86 \pm 0.92$ & $4.08 \pm 0.70$ & 1.22 & $\mathrm{p}>0.05$ \\
\hline $\begin{array}{l}\text { I believed/believe it was/is easy, } \\
\text { comfortable and more convenient for me. }\end{array}$ & $3.28 \pm 0.97$ & $4.19 \pm 0.70$ & 0.91 & $\mathrm{p}>0.05$ \\
\hline
\end{tabular}

Note: Significant level is set at $\mathrm{p}<0.05$. Abbreviations: standard deviation (SD), significance (Sig.) 
Table 3. Descriptive statistics on 3D rat model assessment

\begin{tabular}{|c|c|c|}
\hline & $\mathrm{n}=117$ & $\%$ \\
\hline \multicolumn{3}{|l|}{ Confidence } \\
\hline Strongly Disagree & 0 & 0 \\
\hline Disagree & 0 & 0 \\
\hline Neutral & 16 & 13.7 \\
\hline Agree & 59 & 50.4 \\
\hline Strongly Agree & 42 & 35.9 \\
\hline \multicolumn{3}{|l|}{ Appearance } \\
\hline Strongly Disagree & 0 & 0 \\
\hline Disagree & 0 & 0 \\
\hline Neutral & 15 & 12.8 \\
\hline Agree & 49 & 41.9 \\
\hline Strongly Agree & 53 & 45.3 \\
\hline \multicolumn{3}{|l|}{ Durability } \\
\hline Strongly Disagree & 0 & 0 \\
\hline Disagree & 1 & 0.9 \\
\hline Neutral & 19 & 16.2 \\
\hline Agree & 45 & 38.5 \\
\hline Strongly Agree & 52 & 44.4 \\
\hline \multicolumn{3}{|l|}{ Good and quick method } \\
\hline Strongly Disagree & 0 & 0 \\
\hline Disagree & 0 & 0 \\
\hline Neutral & 0 & 0 \\
\hline Agree & 52 & 44.4 \\
\hline Strongly Agree & 65 & 55.6 \\
\hline
\end{tabular}

\section{Discussion}

The aim of this research was to establish on $3 \mathrm{D}$ model that able to fit for teaching and learning of animal handling and blood withdrawal techniques among undergraduate students. Three- dimensional (3D) printing in the last decades has been successfully utilized in different medical fields, including education. Pre-test data were used to obtain the baseline performance of students before learning the topic. In contrast, post-test data were used to indicate how active the topic is for students after exposure to the 3D printed rat model. The pre and post-test demonstrated that 3D printed rats model can be used as effective learning aid that will able to help knowledge and understanding of blood withdrawal techniques. Based on the result above, it show that students able to identify, handle and withdrawal the blood after exposed with this 3D model rats. They have more confidents and have more knowledge on blood withdrawal techniques.

A technology like STEM (Science, Technology, Engineering and Mathematics) studies and industrial revolution 4.0 (IR 4.0) studies expands more in the current education system where students and educators get more advance knowledge. In the current era, students are being exposed to several types of education technology that expands their level of knowledge and learning in education, and $3 \mathrm{D}$ printing is one of them. In the present 21 st century studies, based on Lei et al. (2016) technologies had brought tremendous opportunities for science education as a result of their capabilities. In this study, the students have learned and improved their hands on in blood withdrawal and improved their spatial visualization. It shows that usage of $3 \mathrm{D}$ printing as an alternative method in the class is very powerful, tremendously versatile, which has the potential to be very accessible to anyone. The use of 3D animal models can reduce the usage of real rats in research studies and students' practices as it can serve as the alternative testing models in research and education that much support the commitment of non-animal based applications. This is in line with the concept of Replacement, Reduction and Refinement (3Rs) that has been recognized as the guiding principles for ethical research in using laboratory animals. According to the 3 Rs concept, the welfare of the animals for research should be considered to make sure that animal use is minimized and animal welfare is improved. This can be achieved by ensuring that the prospective outcome from the research be higher than the burden that is subjected to the animals and that any potential injury or harm caused 
from the experiment is as low as it can be [11].

Based on previous research done by Garcia et al. (2018), creating a 3D printing model requires high anatomical model knowledge and coordination between researcher, surgeon and engineer. It is a relatively straightforward concept but does need some specific multidisciplinary expertise. There are more varieties than one size fits all in this growing field and educational goals, technical expertise and cost are an essential consideration as well. However, an excellent 3D printing model will significantly help us to meet our educational goals, although several factors affecting learning by using $3 \mathrm{D}$ models have been identified in these studies. A study done by Azer \& Azer (2016) suggested that, given the interest in 3D printing anatomy models as evidenced from the increasing number of published research in this area, there is a need for multi-institutional studies that the theories behind learning by $3 \mathrm{D}$ tools and impact of the teaching by 3D models on the enhancement of knowledge, comprehension, clinical skills, integration and application. In this study, by the end of the workshop, almost every student that participated had a good impression on the 3D printed rat model, and they had gained more knowledge of blood withdrawing. Interestingly, the students also agreed that they had gained confidence after utilizing the 3D rat model as their practicing tool.

\section{Conclusions}

Three-dimensional (3D) model usage becomes an alternative tool in this 21 st-century teaching method. The positive response was given by the users on the effectiveness of usability criteria, and three-dimensional (3D) animal model indicates the potential of this courseware for motivating students, whereby it is one of the requirements for a useful aided learning tool. 3D printed rats more effective tools for teaching the blood withdrawal techniques that have been show significant improvement in student's knowledge and understanding compared to conventional teaching techniques. Although 3D model can enhance learning and understanding may have certain benefit over conventional studies using real rats for blood withdrawal, exposure of real rats in teaching still important in term of handling the rats.

\section{Acknowledgements}

Thank you for Universiti Putra Malaysia for the funding under Geran Insentif Penyelidikan untuk Pengajaran dan Pembelajaran 2017 (GIPP 2017; Project Code: 9323733), and Management and Science University for the ethical approval.

\section{REFERENCES}

[1] Lei, J., Luo, P. H., Wang, Q., Shen, J., Lee, S., \& Chen, Y. (2016). Using Technology to Facilitate Modeling- Based Science Education: Lessons Learned from a Meta-analysis of Empirical Research. Journal of Educational Technology Development and Exchange, 9(2).

[2] Morrison, T. J., Sefton, E., Marquez-Chin, M., Popovic, M. R., Morshead, C. M., \& Naguib, H. E.A. (2019). 3D Printed Device for Low-Cost Neural Stimulation in Mice. Frontiers in Neuroscience, 13.

[3] Edwards, Amanda. (2017). The Effectiveness of Model-Based Instruction on Student Achievement and Student Metacognition in Advanced Chemistry Classes. Doctor of Education in Secondary Education Dissertations. 11.

[4] Mishra, P., \& Kereluik, K. (2014). What 21st-century learning? A review and synthesis. SITE Conference.

[5] Lee Ventola, C. (2014). Medical applications for 3D printing: current and projected uses. P \& T: a peer-reviewed journal for formulary management, 39(10), 704-711.

[6] Stieff, M., Bateman, R. C., \& Uttal, D. H. (2015). Teaching and Learning with Three- dimensional Representation. Visualization in Science Education, 93-120.

[7] Garcia, J., Yang, Z. L., Mongrain, R., Leask, R. L., \& Lachapelle, K. (2018). 3D printing materials and their use in medical education: A review of current technology and trends for the future. BMJ Simulation and Technology Enhanced Learning, 4(1), 27-40.

[8] Noordin, S., Fatimah Wan Ahmad, W., \& Kwang Hooi, Y. (2011). Study of Effectiveness and Usability of Multimedia Courseware Integrated with a 3-Dimensional model as a Teaching Aid. International Journal of Computer Applications, 16(4), 20-27.

[9] Augusto I, Monteiro D, Girard-Dias W, dos Santos TO, Rosa Belmonte SL, Pinto de Oliveira J, et al. (2016). Virtual Reconstruction and Three-Dimensional Printing of Blood Cells as a Tool in Cell Biology Education. PLOS ONE

[10] Azer, S. A., \& Azer, S. (2016). 3D Anatomy Models and Impact on Learning: A Review of the Quality of the Literature. Health Professions Education, 2(2), 80-98.

[11] Aimar, A., Palermo, A., \& Innocenti, B. (2019). The Role of 3D Printing in Medical Applications: A State of the Art. Journal of Healthcare Engineering.

[12] Graham, ML \& Prescott, MJ. (2015). The multifactorial role of the 3Rs in shifting the harm- benefit analysis in animal models of disease. European Journal of Pharmacology, 759, 19-29.

[13] Alvarez, F. J. A., Parra, E. B. B., \& Tubio, F. M. ( 2015). Assessment of 3D Models Used in Contours Studies. Universal Journal of Educational Research, 3(11), 877-890.

[14] Alaloul, W. S., Liew, M. S., Zawawi, N. A. W. A., \& Mohammed, B. S. (2018). Industry Revolution IR 4.0: Future Opportunities and Challenges in Construction Industry, MATEC Web of Conferences, 203, 1-7.

[15] Maria L. Streber, Teresa Davila, Gabriel Solano, Lilly 
Esquivel, and Robert Henry. (2011). Production and Use of Plastinated Rat Models for Teaching/Learning Methods for Bleeding. Altex Proceedings, 1/12, Proceedings of WC8.

[16] Aziz Hussin, A. (2018). Education 4.0 Made Simple: Ideas for Teaching", International Journal of Education and Literacy Studies, 6(3), 92.

[17] Basham, J. D., \& Marino, M. T. (2013). Understanding STEM Education and Supporting Students through Universal Design for Learning. Teaching Exceptional Children, 45(4), 8-15.

[18] Burden, N., Chapman, K., Sewell, F., \& Robinson, V. (2015). Pioneering better science through the 3Rs: An introduction to the National Centre for the Replacement, Refinement, and Reduction of Animals in Research (NC3Rs). Journal of the American Association for Laboratory Animal Science, 54(2), 198-208.

[19] Bayram, Servet \& Nous, Albert. (2002). Evolution of educational software evaluation: Instructional software assessment. The Turkish Online Journal of Educational Technology.

[20] Doke, S. K., \& Dhawale, S. C. (2015). Alternatives to animal testing: A review", Saudi Pharmaceutical Journal, 23(3), 223-229.

[21] Fina, F., Goyanes, A., Gaisford, S., \& Basit, A. W. (2017). Selective laser sintering (SLS) 3D printing of medicines. International Journal of Pharmaceutics, 529(1-2), 285-293.

[22] Groth, C., Kravitz, N. D., Jones, P. E., Graham, J. W., \& Redmond, W. R. (2014). Three- dimensional printing technology. Journal of Clinical Orthodontics: JCO, 48(8), $475-485$.

[23] Gu, Q., Hao, J., Lu, Y. J., Wang, L., Wallace, G. G., \& Zhou, Q. (2015). Three-dimensional bioprinting. Science China
Life Sciences, 58(5), 411-419.

[24] Knowlton, S., Yenilmez, B., \& Tasoglu, S. (2016). Towards Single-Step Biofabrication of Organs on a Chip via 3D printing. Trends in Biotechnology, 34(9), 685-688.

[25] Kretlow, A., Butzke, D., Goetz, M. E., Grune, B., Halder, M., Henkler, F.Luch, A. (2009). Implementation and enforcement of the 3Rs principle in the field of transgenic animals used for scientific purposes. Report and recommendations of the BfR expert workshop, May 18-20

[26] Kumar, M., Dandapat, S., Prasad Sinha, M., Kumar, A., \& Raipat, B. S. (2017). Different blood collection methods from rats: A review. Balneo Research Journal, 8(2), 46-50.

[27] Liebsch, M., Grune, B., Seiler, A., Butzke, D., Oelgeschläger, M., Pirow, R., Luch, A. (2011). Alternatives to animal testing: Current status and future perspectives. Archives of Toxicology, 85(8), 841-858.

[28] Parasuraman, S., Raveendran, R., \& Kesavan, R. (2010). Blood sample collection in small laboratory animals. J Pharmacol Pharmacother, 1(2), 87-93.

[29] Taylor, K., Gordon, N., Langley, G., \& Higgins, W. (2008). Estimates for worldwide laboratory animal use in 2005. ATLA Alternatives to Laboratory Animals, 36(3), 327-342.

[30] Wu, A.-M., Wang, K., Wang, J.-S., Chen, C.-H., Yang, X.-D., Ni, W.-F., \& Hu, Y.-Z. (2018). The addition of 3D printed models to enhance the teaching and learning of bone spatial anatomy and fractures for undergraduate students: a randomised controlled study. Annals of Translational Medicine, 6(20), 403-403.

[31] Zou, W., Yang, Y., Gu, Y., Zhu, P., Zhang, M., Cheng, Z. Peng, X. (2017). Repeated blood collection from the tail vein of non-anesthetised rats with a vacuum blood collection system. Journal of Visualized Experiments, 2017(130), 1-6. 